\title{
MEDIUM AND LARGE HAIL IN TRANSYLVANIA, LOCALITY OF BAND, 24th MAY 2015
}

\author{
Răzvan Alexandru SOMESAN ${ }^{1,2}$, Grigore MAKKAI ${ }^{2}$
}

DOI: 10.21163/GT_2016.111.09

\begin{abstract}
:
This paper presents an analysis of synoptic and mesoscale phenomena that led to the severe weather in Mures County (Romania) on 24th-25th May 2015, as well as the registration of large hail in the locality of Band. For the synoptic analysis ECMWF numerical model outputs were used, ALARO, COSMO limited area models, visible and infrared satellite images, maps and weather reports used in forecasting and in meteorological diagnosis, radar data imaging and data processing, provided by the Doppler WSR - 98D radar in Bobohalma, the Skew-T charts in Târgu Mures, data from Targu Mures weather station, data from the pluviometry stations, signs of instability. Through these sources and procedures a multicellular type mesoscale convective system was identified on May 24th 2015. The areas where hail was reported were located within the county, but also in its vicinity, and the route of its movement was examined, as well as its size on consecutive the radar scans.
\end{abstract}

Key-words: Hail, Cumulonimbus, Instability, ECMWF, Doppler WSR

\section{INTRODUCTION}

May is the most unstable month of spring when, typically, large amounts of rainfall are registered in the Transylvanian Depression. During the warm season, most of the precipitation accumulated comes from convective clouds. In Romania the formation and the evolution of convective clouds is greatly influenced by the varied relief. The hilly and mountainous areas are often affected by dangerous meteorological phenomena such as strong rain showers associated with rapid flooding, hail and wind intensification. Mures County is a complex county in terms of relief, between the Transylvanian Plain to the west and the Eastern Carpathians to the east. During the summer season it is often affected by severe weather events such as hail, torrential rain, strong wind with storm, electric discharge. The emergence of hail is linked to cumulonimbus clouds with great vertical development ( $\mathrm{Cb}$ Capillatus), where there are intense updrafts and descendant drafts. Among the first studies on the possibility of capitalization of radar echoes in defining areas with hail are developed by Waldvogel, Federer and Grimm (1979) and Waldvogel (1983). Witt (1996) uses reflectivity at $0.5^{\circ}$ elevation to separate the storm nuclei containing rain from those with hail content. Regarding the formation of hail in connection with the dynamic of the storm super-cell, Weisman (1996) and Blanchard (1998) take into account the potential of the available convective energy. In order to estimate the diameter of the hail Paxton and Shepherd (1993), Amburn and Wolf (1997), Lahiff (2005) indicate VIL-density derivative product. This represents the ratio between VIL and Echotop (the height of the cloud), ie it is the amount of water per $\mathrm{km}$ in relation to cloud height. Blaes, Cerniglia and Caropolo (1998) indicates for VIL density thresholds $4-4.5 \mathrm{~g} / \mathrm{m}^{3}$, to probabilistically separate severe hail cells from the least severe ones.

\footnotetext{
${ }^{1}$ University of Lorraine, 57006 Metz, France, somesan_r@yahoo.com.

${ }^{2}$ Local Meteorological Centre of Târgu Mureş, 540190 Târgu Mureş, Romania.
} 
The aim of the present article is to introduce the conditions of the formation of medium and large sized hail, in connection with the evolution of atmospheric instability indices. The case study is devoted to the analysis the synoptic and mesoscale conditions that led to the severe weather events of May 24 in Mures County and the occurrence of large hail in the locality of Band.

\section{DATA AND METHODS}

There are a number of practical methods and techniques for establishing the estimative parameters of the degree of instability and the possibility of producing thunderstorms, strong wind gusts, rain and hail showers. This category includes Showalter Index, Lifted Index, K Index, Vertical Totals, CAPE and other similar ones. They generally use the values of temperature and moisture of the standard isobaric levels or a combination thereof. The numerical models supply values of the indices of instability, under prognosis on different time intervals.

We note most significant contributions on the conditions of formation of hail in Transylvania in the form of articles Maier and Haidu (2011), Tudose and Haidu (2012), respectively, larger studies as doctoral thesis Maier (2011) and Tudose (2013). Haidu and Tudose (2014) show a validation procedure for statistical indices of atmospheric instability involved in the occurrence of heavy rains and hail from Transylvania. Nucuţa (2012) associates violent manifestations of severe weather accompanied by heavy rain and large hail structures Enhanced-V, and provides examples for all Romania. Similar weather conditions are possible in other parts of Transylvania, for example south of the Apuseni Mountains (Győri \& Haidu, 2011) hail having with disastrous effects, and against the background of heavy rain flash-floods emerged.

In the present article following indices of instability were used:

\section{Lifted Index (LI)}

$$
\mathrm{LI}=\mathrm{T}(500 \mathrm{mb})-\mathrm{T}_{\mathrm{p}}(500 \mathrm{mb})
$$

where: $T_{p}$ is the temperature of the air particle ramped adiabatically (dried to the condensation level, then saturated), on the ground surface, up to $500 \mathrm{mb}$. The unit of measurement is ${ }^{\circ} \mathrm{C}$.

- $\quad$ LI $>3$, stable air mass

- $\quad 1<\mathrm{LI} \leq 3$, slight instability, showers

- $\quad-1<\mathrm{LI} \leq 1$, instability, showers and electric discharge

- $\quad-3<\mathrm{LI} \leq-1$, moderate instability, wide area storms

- $\quad-6<\mathrm{LI} \leq-3$, strong instability, severe storms;

- $\quad \mathrm{LI} \leq-6$, extreme instability, wide area severe storms, tornadoes

K Index (KI) $\mathrm{KI}=\mathrm{T}(850 \mathrm{mb})-\mathrm{T}(500 \mathrm{mb})+\mathrm{T}_{\mathrm{d}}(850 \mathrm{mb})-\left[\mathrm{T}(700 \mathrm{mb})-\mathrm{T}_{\mathrm{d}}(700 \mathrm{mb})\right]$

Indicates the likelihood of non frontal storm occurrence, the convective summer storms which are formed within the same air masses. The unit of measurement is ${ }^{\circ} \mathrm{C}$.

The relationship between $\mathrm{KI}$ and the probability of occurrence of the storm is:

- $\quad \mathrm{KI}<21:<19 \%$

- $21 \leq \mathrm{KI} \leq 25: 20-39 \%$

- $26 \leq \mathrm{KI} \leq 30: 40-59 \%$

- $\quad 31 \leq \mathrm{KI} \leq 35: 60-79 \%$

- $36 \leq \mathrm{KI} \leq 40: 80-89 \%$

- $\mathrm{KI}>40:>90 \%$ 


\section{Convective Available Potential Energy (CAPE)}

The CAPE of air the particles can be calculated using the data from an aerologic survey or those provided by a numerical model.

$$
C A P E=\int_{z_{b}}^{z_{h}} g \frac{T_{p}-T_{m}}{T_{m}} d z
$$

where: $g$ is the gravitational acceleration, $z_{b}$ is the level of free convection, $z_{h}$ the neutral ascension level, $T_{m}$ ambient temperature, and $T_{p}$ the temperature of the rising air particle. Its unit of measure is $\mathrm{J} / \mathrm{kg}$.

- $\quad$ CAPE $<1000$, marginal instability

- $1000 \leq \mathrm{CAPE}<2500$, moderate instability

- $2500 \leq \mathrm{CAPE} \leq 3500$, strong instability

- $\mathrm{CAPE}>3500$, very strong instability

\section{THE SYNOPTIC AND MESOSCALE ANALYSIS}

For the synoptic analysis ECMWF numerical model outputs were used, ALARO, COSMO limited area models, visible and infrared satellite images, maps and weather reports used in forecasting and in meteorological diagnosis, radar data imaging and data processing, provided by the Doppler WSR - 98D radar in Bobohalma, the Skew-T charts in Târgu Mures, data from Targu Mures weather station, data from the pluviometry stations.

The synoptic and mesoscale analysis is based on the background of high temperatures (maximum temperatures were between 24 and $29^{\circ} \mathrm{C}$, the maximum ground temperatures at Targu Mures weather station reached levels of $43-44^{\circ} \mathrm{C}$ ), good weather during 19 to 22 May gradually destabilized. On May 24th the weather was hot but generally unstable, therefore rainshowers were reported (Table 1), accompanied by lightning, strong wind and medium and large size hail.

Table 1. Amount of precipitation on 24.05.2015.

\begin{tabular}{|c|c|c|c|}
\hline Name of the locality & Amount (1/mp) & Name of the locality & Amount (1/mp) \\
\hline Târgu Mures & 0.2 & Band & 9.3 \\
\hline Sărmas & 0.6 & Glodeni & - \\
\hline Batos & 1.8 & Reghin & 2.2 \\
\hline Târnăveni & 0.0 & Lăpusna & 5.3 \\
\hline Ludus & 0.2 & Gurghiu & 7.5 \\
\hline Sânger & 2.5 & Gălăoaia & 11.2 \\
\hline Sighisoara & - & Răstolita & 0.7 \\
\hline Sovata & - & Stânceni & - \\
\hline
\end{tabular}

Starting with May 24th, ANM issued several weather briefings on increased atmospheric instability valid until May 27th 18:00, for the following phenomena: showers with torrential aspects, frequent electric discharge, short duration wind intensification with storm aspects, hail and amounts of water that will exceed locally $15-20 \mathrm{l} / \mathrm{sqm}$ and in isolated areas 30-40 1/sqm, especially in the northern and central territory, as well as in hilly 
and mountain areas. As a result of the intensification of the weather phenomena it was necessary to issue three yellow code nowcasting warnings for Mures county by SRPV Sibiu. The concerned phenomena were: rain showers that will exceed 25-30 1/sqm, medium and large size hail, lightning, strong wind, which can sometimes be storm-like. At ground level Romania was dominated by a depressionary regime since May 19. On May 22nd a $1010 \mathrm{mb}$ pressure cyclone forms in the southwest of the country. This expanded on May 24th across the Balkan peninsula and over the western part of the Black Sea.

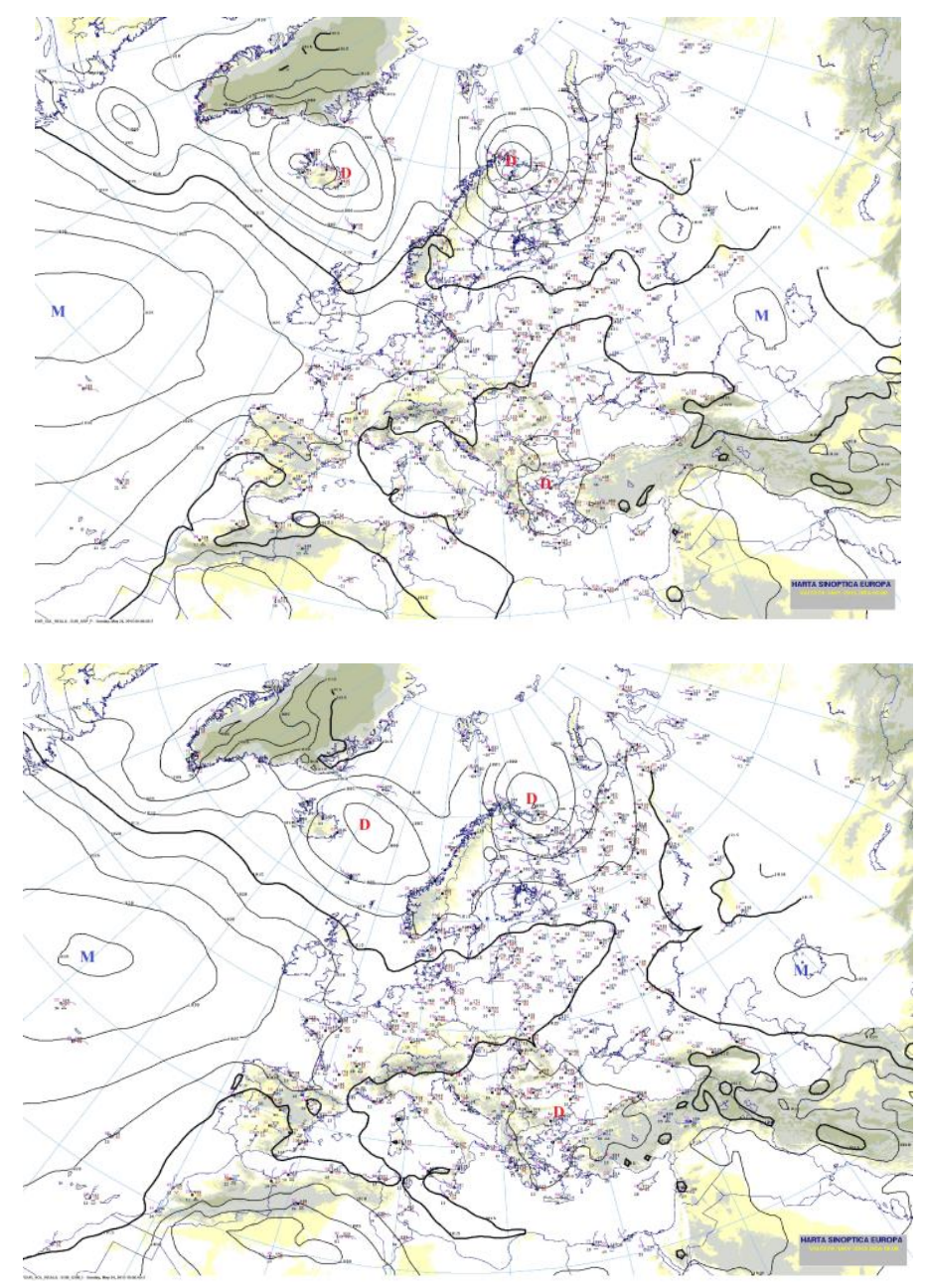

Fig. 1 The synoptic maps of 24 May 00 (up) and18 (down).

On the synoptic maps (Fig. 1) one can note the Azores High with a core of $1035 \mathrm{mb}$, the dorsal extended over the UK and Western Europe. In the north-western part of Europe there was an Icelandic cyclone with a pressure center of $995 \mathrm{mb}$, and in northern Scandinavia there was a cyclone with a pressure of $990 \mathrm{mb}$. At the same time, in Eastern Europe there was a core anticyclone with a pressure of $1020 \mathrm{mb}$. 
At the level of $850 \mathrm{hPa}$ from May 21 until May 25 the temperature did not undergo large changes, with values $12-14^{\circ} \mathrm{C}$, but starting with May 26 the temperature fell gradually, reaching a value of 29 to $5^{\circ} \mathrm{C}$. At the level of $500 \mathrm{hPa}$, on May 23 the geopotential began to decline, with values close to $24570 \mathrm{dmgp}$. On the map (Fig.2) it can be seen that The Azores High extends its dorsal over west-central Europe. In northern Scandinavia there was a cyclone, which expanded its thalweg to central Europe. In southwest Romania there was a core cyclone, with a mass of cold air of $-20^{\circ} \mathrm{C}$. Romania is on the front of the thalweg. The geopotential decreased in the last 24 hours by $4 \mathrm{dmgp}$ (564 dmgp instead of $568 \mathrm{dmgp}$ ). The temperature at this level had large oscillations, between 17 and $-15^{\circ} \mathrm{C}$. The circulation of the height was southern.

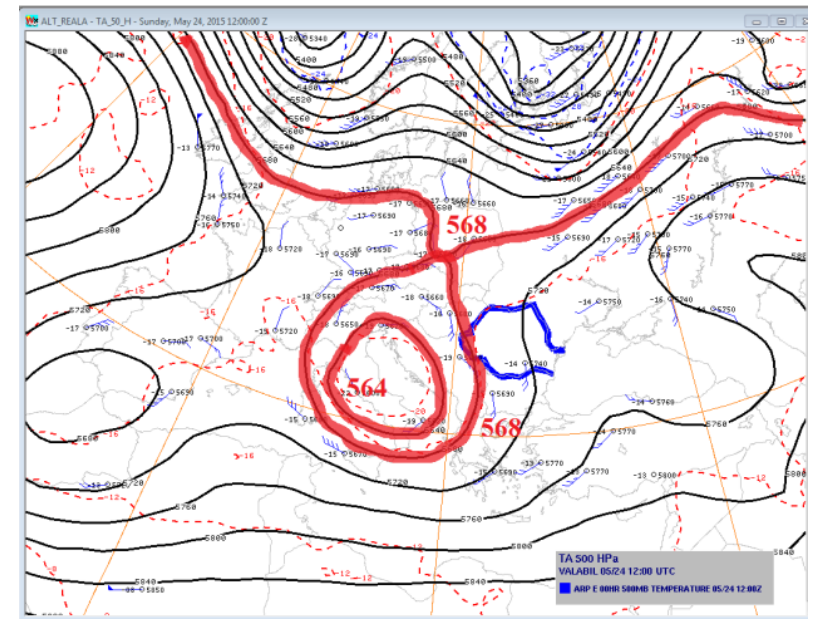

Fig. 2 Real map at $500 \mathrm{hPa}$ from 24.05.2015 at 12.

Regarding the analysis of radar products, and primarily reflectivity, we mention the first appearance of storm cells at 15.59 UTC northeast of the locality of Band, moving along the SE-NW direction (Fig. 3). The highest values of reflectivity are registered at level 4 (60 DBZ) northeast of the locality of Band. As a result of the evolution of the cell it is found that the cell system became quasi-stationary over the localities of Band and Marasesti for about 30 minutes. In the timeframe UTC 16.12 - 16.24 UTC the storm reached its peak development, reflectivity having very high values $(70-71 \mathrm{dBz})$. At 16.43 reflectivity fell below 55 DBZ. On the radar images it can be seen that the cellular systems are organized under the form of mesoscale convective system, as a multicellular type. In the evening, when instability was accentuated, more convective cells were formed with reflectivity of more than 60 DBZ. Some cells develop, while others are dissipating. At 15.59 UTC cloud height reaches $10 \mathrm{~km}$ and at 16.18 UTC in Band it is $12 \mathrm{~km}$.

In the J7 cell (Table 2) at 15.59 UTC hail formed with a diameter of $1.91 \mathrm{~cm}$. The diameter of the hail estimated by the radar from Bobohalma was higher in the next 4 scans, with increasing of cloud height, at 16.18 UTC it was $9.53 \mathrm{~cm}$, destroying hundreds of hectares of farmland and the rooftops in the locality of Band and the echo top up to 10.851 meters. After 16.24 UTC the diameter of hail started to decrease $(5.71 \mathrm{~cm})$, with a diameter of $1.27 \mathrm{~cm}$ at $16.37 \mathrm{UTC}$. 


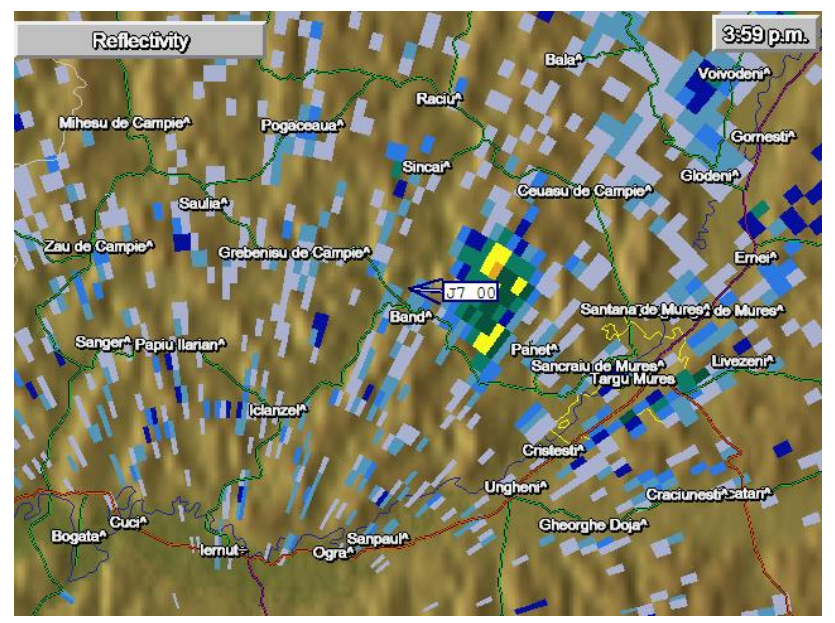

Fig. 3 Appearance of the first cells near the locality of Band 24.05.2015.
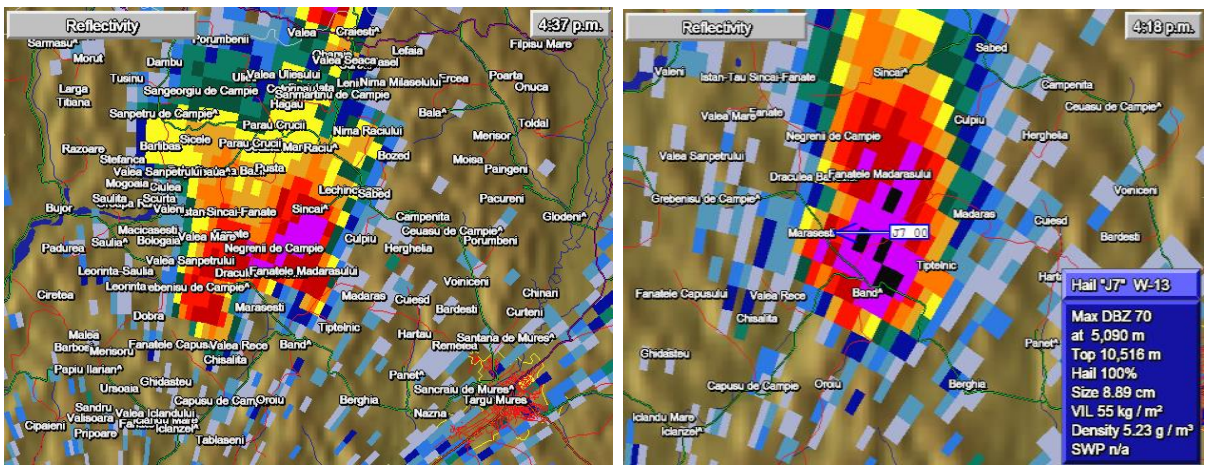

Fig. 4 Reflectivity at 16.37 UTC (left) and 16.18 UTC (right).

Regarding the hourly precipitation amounts, we mention the fact that at 16.15 UTC the amount of precipitation reached $10 \mathrm{l} / \mathrm{sqm}$, at $16.21 \mathrm{UTC}$, the amount of precipitation accumulated in an hour northeast of the locality of Band reaches 15-20 1/sqm, at 16.40 UTC $55 \mathrm{l} / \mathrm{sqm}$, and at $16.46 \mathrm{UTC}$ the amount of precipitation reached $651 / \mathrm{sqm}$ south of the locality of Râciu. At 12.45 UTC the upper surface temperature of the cloud had values of $60^{\circ} \mathrm{C}$, being maintained until 14.45 UTC in the north of the Eastern Carpathians. After 17:30 UTC upper surface temperature of the clouds gradually decreased reaching around $25^{\circ} \mathrm{C}$ in one hour. $1 \mathrm{kmHRV}$ resolution visible satellite images show that convective cells first appear after 12 UTC in the north of the Eastern Carpathians. In the central eastern Transylvania, the cells appear after 14 UTC, developing quickly due to the southern movement and the timing of the maximum daytime warming (thermal convection). Around 15 UTC, the first storm appears in the southern part of the Mures county, it develops over time, reaching the peak at around 16-17 UTC in Mures county, when the height of the clouds surpassed $10 \mathrm{~km}$. At 17 UTC one can observe a more intensive development of the cloud system, moving toward the north. After 17 hours UTC the height of the clouds falls below $8 \mathrm{~km}$ in Mures county. 
Table 2. The features of hail in $\mathrm{J} 7$ cell.

\begin{tabular}{|c|c|c|c|c|c|}
\hline UTC Time & $\begin{array}{c}\text { Hail } \\
(\mathrm{cm})\end{array}$ & $\begin{array}{c}\text { Reflectivity } \\
(\mathrm{dBz})\end{array}$ & $\begin{array}{c}\text { VIL } \\
(\mathrm{Kg} / \mathrm{mp})\end{array}$ & $\begin{array}{c}\text { Echo top } \\
(\mathrm{Km})\end{array}$ & Area \\
\hline 15.53 & $<1.27$ & 50 & 10 & 7,650 & NE Band \\
\hline 15.59 & 1.91 & 59 & 31 & 7,529 & NE Band \\
\hline 16.06 & 4.45 & 65 & 48 & 9,693 & NNV Band \\
\hline 16.12 & 8.89 & 70 & 55 & 10,516 & N Band \\
\hline 16.18 & 9.53 & 71 & 58 & 10,851 & $\begin{array}{c}\text { NNE } \\
\text { Mărăsesti }\end{array}$ \\
\hline 16.24 & 5.71 & 71 & 57 & 11,095 & $\begin{array}{c}\text { Negrenii de } \\
\text { Câmpie }\end{array}$ \\
\hline 16.30 & 2.54 & 67 & 37 & 8,717 & V Sincai \\
\hline 16.37 & 1.27 & 66 & 27 & 6,401 & $\begin{array}{c}\text { NNV Sincai - } \\
\text { Fânate }\end{array}$ \\
\hline 16.43 & - & - & 10 & 1,615 & - \\
\hline
\end{tabular}

Aladdin numerical model indicates that the initiation of convection at 6 UTC the CAPE had values of 1500-200 J/kg, at 12 UTC the CAPE estimated values of 4000-4500 $\mathrm{J} / \mathrm{kg}$, this value being maintained even at $15 \mathrm{UTC}$, which means strong instability. The moisture convergence (MOCON) indicated low values: $5 \mathrm{~g} / \mathrm{kg} / \mathrm{s}$. For 12 UTC LI, KI, TTI indices and the amount of precipitable water showed strong storm, CAPE and CIN indices had moderate values. According to the Skew-T diagram in Târgu Mures, the wet bulb zero level is at $680 \mathrm{mb}(3200 \mathrm{~m})$ on 24th May.

\section{CONCLUSIONS}

In this article we located the areas of the county, but also in its vicinity, using the Doppler radar from the Târnăveni weather station (Bobohalma), where the hail was reported and the route of its movement, as well as its size were watched on the consecutive radar scans. Using the radar at the Tărnăveni (Bobohalma) weather station and the HRV 1 $\mathrm{km}$ from EUMETSAT visible resolution satellite images a mesoscale convective system of multicellular type was identified on May 24th 2015. Comparison of theoretical thresholds of the severity of the instability parameters with the intensity of the observed convective phenomena at Bobohalma Doppler radar and suggested by the satellite images show that the clues from the COSMO survey forecast had a good behaviour.

The high instability was due to the following factors:

- at ground level a core cyclone formed

- in altitude, Romania is on the front of the thalweg

- movement predominantly southern carrying a tropical air mass (temperatures $5-6^{\circ} \mathrm{C}$ above the monthly average, at $850 \mathrm{mb}$ )

- storms began at the moment of maximum daytime warming

- the maximum ground temperature at the Târgu Mures station had high values (42 $44^{\circ} \mathrm{C}$ ), for a week

- the Mediterranean cyclone that reached the South of the country on May 23rd causing strong upward drafts associated with severe convective phenomena, due to hot and humid air carried in front of the cyclone: medium and large sized hail, strong wind and torrential rain showers. 
We mention, in this conclusion, some media reports about the weather events of May 24th 2015 the Band.

"In the locality of Band, Mures county, the storm came rapidly before dusk. It was as if it was raining quail eggs and even chicken eggs, say the witnesses. It lasted about 10-15 minutes, in just a few moments the vegetables in the gardens ended up like a sort of porridge, and the field crops were destroyed up to 80\%. The hail smashed windows, but also damaged cars "(source: www.stirileprotv.ro).

\section{R E F E R E N C E S}

Amburn, S. A. \& Wolf, P. L. (1997) Vil density as a hail indicator. Weather and Forecasting, 12, 473-478.

Blaes, J. L., Cerniglia, Jr C. S. \& Caropolo, M. A. (1998) Vil density as an indicator of hail across eastern New York and western New England. Eastern Region Tehnical Attachment, 98-8, September 1-17.

Blanchard, D. O. (1998), Assessing the vertical distribution of convective available potential energy. Weather and Forecasting, 13, 870-877.

Győri, M.-M. \& Haidu, I. (2011) Unit hydrograph generation for ungauged subwatersheds. Case study: the Monoroştia river, Arad County, Romania. Geographia Technica, 6 (2), 23-29.

Haidu, I. \& Tudose, T. (2014) Validation of Several Atmospheric Stability Indices for the Storms Generating Torrential Rain Showers in the North-West of Romania. Studia Universitatis BabeşBolyai, Ser. Geographia, 59 (1), 37-46.

Lahiff, C. T. (2005) Vertically integrated liquid density and its associated hail size range across the Burlington, Vermont county warning area. Eastern Region Technical Attachement, 05-01 June, $1-20$.

Maier, N. (2011) The study of atmospheric instability and radar echoes in order to achieve the forecast of "now casting" rainfall in the Apuseni Mountains. PhD Thesis, "Babeş-Bolyai" University Cluj-Napoca.

Maier, M. \& Haidu, I. (2011) Radar climatology of hail in the Apuseni Mountains. Aerul şi Apa Componente ale Mediului, vol. 3. ISSN: 2067-743X.

Nucuţa, C. (2012) The analysis of the enhanced-v structures atop tornado storms across Romania. Geographia Technica, 7 (1), 72-82.

Paxton, C. H. \& Shepherd, J. M. (1993) Radar Diagnostic Parameters as Indicators of Severe Weather in Central Florida. NOAA Tech. Memo. National Weather Service-Technical Report, p.12.

Tudose, T. \& Haidu, I. (2012) Some aspects of the relationship between synoptic-scale wind and convective cells' motion generating heavy rains in the north-western Romania. Aerul şi Apa Componente ale Mediului, vol. 3. ISSN: 2067-743X.

Tudose, T. (2013) Genetic characteristics and spatial-temporal manifestations of heavy and maximum annual intensity rains in northwestern Romania. PhD Thesis, "Babeş-Bolyai" University Cluj-Napoca.

Waldvogel, A., Federer, B. \& Grimm, P. (1979) Criteria for the Detection of Hail Cells. J. AppL Meteor., 18, 1521-1525.

Waldvogel, A. (1983) Détection et mesure de la grêle par radar. La Houille Blanche, 5/6, 411-420.

Weisman, M. L. (1996), On the use of vertical wind shear versus helicity in interpreting supercell dynamics. Preprints, 18th Conf. on Severe Local Storms, San Francisco, CA, Amer. Meteor. Soc.

Witt, A. (1996) The Relationship Between Low-Elevation WSR-88D Reflectivity and Hail at the Ground Using Precipitation Observations from the VORTEX Project. NOAA/ERL/National Severe Storm Laboratory, Norman, Oklahoma. 